\title{
Religion and the media: reflections on their position and relationship in Southern Africa
}

\author{
Muhammed Haron
}

\begin{abstract}
In this essay an attempt is made to reflect upon, and to provide, a general overview of the position of the media and religion and the relationship between these two sectors in Southern Africa. Instead of covering the vast Southern African region, it will confine itself to reviewing the position and interconnection of these elements in specific countries. Before contextualising religion and the media in a given region, there is a need to construct a theoretical framework that will assist the understanding and nature of this relationship.
\end{abstract}

\section{Introduction}

Although religion and the media have enjoyed adequate scholarly attention in the USA and elsewhere in the European world, the area is still very much an untapped sector in Southern Africa. Despite the presence of numerous media studies programmes and religious studies courses in the region, and even though there have been some signs of interest in this area, research on the relationship between "religion and the media" has not as yet taken off as a viable field of focus. As a consequence, none of the region's tertiary institutions such as the University of KwaZulu-Natal, Rhodes University, University of Botswana and the University of Zimbabwe, as far as could be ascertained, has given serious thought in devoting itself to specifically concentrating on the connection between these two areas of specialisation.

Coinciding with the onset of globalisation, the region has witnessed the steady growth of the media industry and the gradual emergence of various strands of religious activism. In the media industry, there has been a major shift from the production of the traditional print media to the electronic media, and in the arena of religion there has been a marked increase in evangelical and fundamentalist activities employing the media to promote and advocate their evangelical ideas; a few publications have, in fact, demonstrated how the last-mentioned groups have increasingly employed media as a vehicle to spread "Good News" (Schultze \& Woods, 2008). These shifts and changes have raised a variety of questions regarding the impact that religious thinking has 
had on socio-political sectors and to what extent the media (print and electronic) have managed to capture, report and analyse these (religious) developments.

\section{Constructing a theoretical framework: Religion: defining the term}

Many definitions have been proffered by scholars and it will be best to avoid the wide variety that has been tabled. For the purposes of this essay, we confine ourselves to a selected few that fall within the scope of our discussion. In a fairly informative text (Crawford, 2002: 1-8) entitled in his first chapter: "Can religion be defined?" From among the list that he recorded are the following noteworthy ones: Emile Durkheim argued that: 'religion is a unified system of beliefs and practices relative to sacred things, that is to say, things set apart and forbidden, beliefs and practices which unite into one single community called a church, [and] all those who adhere to them,' and Ninian Smart averred that 'religion is a seven dimensional organism, ritual, doctrinal, mythical or narrative, experimental or emotional, ethical or legal, organizational or social, material or artistic.' In addition to making reference to these and a host of other scholars, Crawford also mentioned Smart who, in turn, drew upon John Hick, the renowned philosopher of religion; the latter declared that '[r]eligion is one thing to the anthropologist, another to the sociologist, another to the psychologist..., another to the Marxist... and yet another to the Jew or Christian.... and [t]here is, consequently, no universally accepted definition of religion, and quite possibly there will never be.' Leaving aside Crawford's list, we go to Corbett \& Corbett (1997) who asserted that religion is 'an integrated system of beliefs, lifestyle, ritual activities, and institutions, which people give meaning to in their lives by orienting themselves to what they take to be holy, sacred, or of ultimate value.' It can be concluded from the recorded lists that while attempts were made to neatly define the term, social scientists could not agree on a specific definition because of the variety of approaches that have been adopted in order to fully grasp and understand how religion relates and influences social behaviour. However, when we return to the above definitions we consider Corbett \& Corbett's to be a fairly comprehensive definition which alludes to the fact that religion is "a way of life" as maintained by adherents to the major and minor religious traditions and one that encompasses a range of aspects.

When evaluating "religion" during the contemporary period one cannot escape the fact that "the secularisation thesis" has played a critical role in the way it has been and is being perceived in the contemporary world (Bruce, 1996: 37-39, 52-59; Robbins \& Anthony, 2007: 7-8). The latter thesis, which has held sway in North American/European scholarship for much of the $20^{\text {th }}$ century, essentially argued that religion, which has been associated with mystery and the intangibles, has declined and almost disappeared in many parts of the developed nation-states such as France and Great Britain. In these developed nation-states religion has steadily been privatised and, in the end, it has effectively been isolated; and secularism, which has been linked 
to materialism and with whatever could be identified as tangible, took its place as the rightful heir in the modernised, progressive world. Since secularism as a phenomenon has been undergirded by the process of rationalisation, each and every act performed by the individual has since been viewed as measured, calculated and conceptualised via the individual's "rational choice."

With secularism taking root and making its presence felt in all sectors of social life, God, who is said to have been the creator and fashioner of religion and the one with whom mystery and the intangible world has always been associated, has been displaced by the rationally-minded individual; the latter's ability to make informed rational decisions and choices in terms of the work or deed that he/she desires or wished to perform sets him/her apart from God's handiwork. In the modern world, the upholders of secularism have not only vehemently argued against God's non-existence but they have also proffered views regarding God's irrelevance in human affairs and it is exactly these ideas that influenced and affected the media industry that adopted a purely secular approach to world affairs and, in the process, marginalised religion.

\section{Religion and the media: a relationship?}

As a consequence of the weak position religion held in the eyes of those living in the developed world, Cultural Studies - and more specifically Media Studies - specialists influenced by particular European-based theoretical schools, not only ignored its presence but scorned it wherever and whenever religion was encountered (Clark \& Hoover, 1997: 23) and asserted that other critical observers in the arena of Cultural Studies stated that religion was sidestepped because of socio-political explanations such as the role of religion in class formations and communal conflicts. And since religion was tied to particular classes or elite groups within communities that were embroiled in conflicts, Clark et al claimed that '(r)eligion has too facilely been dismissed as a hegemonic force whose only role is to frame competing definitions of reality and, in doing so, suppress ideas and conflicts.' Clark et al, (1997: 26-28) showed how media, which is a fairly broad term that encompasses the respective print and electronic sectors, and religion through ritual studies tangibly intersected. Furthermore they invoked the names of scholars such as Robert Wuthnow and Mary Douglas who bridged the gap between respective disciplines of Religious Studies and Cultural Studies.

In fact, towards the end of the $20^{\text {th }}$ century and, more specifically, as Hoover (2006:18) admitted, by 1979, there was a sea change when religion re emerged in Iran (and for that matter in Nicaragua) as a significant phenomenon, and as a critical player in global affairs. Religion not only deeply affected world affairs but firmly influenced socio-political activities at all levels in such a manner that western-trained social scientists, at that time, could ill-afford to ignore it as a phantom that only returned to haunt them since it was ousted in an unceremonious way during the $19^{\text {th }}$ century. What they all gradually acknowledged was that religion resurfaced to reclaim that position, which it had lost to secularism in the developed - and not, we need to stress, in the developing - world by the end of the $19^{\text {th }}$ century. This was the case, as Murdoch (1997: 95) 
correctly pointed out, because of three basic factors: "the loss of faith in "progress", the intensified sense of meaningless at the heart of modernity, and the consumer's increasing inability to compensate.' Since it has reappeared in a very forceful and dramatic fashion, the media as a public instrument has mediated religious phenomena in a manner that was far from positive; its re-entry may be described as one that was unwelcome and scorned. And as a result of the type of negative reporting by the predominantly Western media about Muslims and Islam a tendentious relationship developed that forced Muslims to view the Western oriented media with suspicion. Edward Said brilliantly demonstrated in his classical work Orientalism (1987) and Covering Islam (1981) the tense relationship that developed between the West and the "mystical" Orient; in these works Said revealed how Western media reported on Islam and Muslims and consequently influenced the perceptions of the reader/listener/viewer and to what extent it could sway American/European public opinion towards religious communities from the East. In fact, Said showed the power that the media wielded in mediating information to its target audience; the radio and TV being amongst the most effective.

\section{Religion and the media: the question of power}

Indeed, the electronic media represented by radio and $\mathrm{TV}$ has demonstrated its power to influence people's perceptions and communal opinions. In this regard, the following questions readily come to mind: What does power actually entail? Does power mean the same in the sphere of religion as it does in the media? Why is it such a critical concept? And how does it affect change? These are but some of the questions that one has to consider when evaluating the concept and when viewing it as a core element in the media's performance within the context of the public sphere and religion's impact on social life. We therefore begin with how religion and power interconnects and here we rely heavily on the work of Beckford $(1983 ; 2007)$. In the latter's radically revised article, he demonstrated how these two terms are linked to one another. Before showing the connection, he reviewed the works of two significant sociologists of religion, namely Peter Berger and Thomas Luckmann and noted that both scholars inserted the term "power" when discussing religion, but they did not analyse the concept in any detail. In Beckford's view, they neglected to write power into the sociology of religion.

Berger's usage, he argued, was "very abstract and disembodied" and Luckmann excluded it from his agenda. He was astonished at the way these two scholars [mal]treated this concept. He went on to carefully reflect upon it by discussing the concept under 6 separate headings suggesteing that power confounds, convinces, contests, controls, cultivates and cures. For the purposes of our essay we are only concerned with how it contests and controls. Since Luckmann's (ibid 52-53) reference point was the USA, he briefly discussed the Moonies' desire to contest the power of the American Civil Religion, and he (ibid) reflected on the position of the New Christian Right (NCR), which has exercised its influence and power with the intention of controlling, in the political arena, legal sector and social sphere. In each case - as well as others - the NCR has been 
aware of the important position it holds within American civil society and how power can be manipulated and mediated to maintain its influence and retain its control over outcomes. What Beckford (2007: 58) essentially did was to propose that 'empirical attention... be focused on the reported experiences and the perceived manifestation of power and power struggles in religion.' When we cast our sights on the term as it operates within the media sector, then we observe that it has similar and different functions.

The noted scholar, Hebert T. Altschull, wrote Agents of power: the media and public policy in which he spelt out the state of power in the media. Before Altschull (1995: 52-53) highlighted the position of power vis-à-vis the media, he stressed the limits of the press and discussed this in relation to its contents that are determined by four stakeholders: the government, the advertising agencies, the financiers and the lobbying groups. Altschull (1995: 70-72) honed in on the "power of the press" and earmarked on what he termed "articles of faith", the first of which is that the press must be free from outside interference, the second of which is that it should seek to learn and present the truth, the third of which is that it should serve the public who has a right to know, and that it should report facts objectively. He emphasized the point that the media is an instrument and not an independent actor as some might wish it to be, and he further underlined the position that the media are 'agents of power rather than wielders of power' (1995:77). In relation to what Altschull accentuated, Curran \& Seatorn (1997: 169; 270) remarked that the media is not an 'instrument of crude propaganda' and that writers and researchers credit the media with power to influence people, persuade individuals, set agendas, frame issues, change communal attitudes and even affect social behaviours. Regarding one of Altschull's lastmentioned points, we may posit the view that religion is also an agent of power and not a wielder of power; however, it is precisely in this sector where the issue is contested and this depends entirely upon the individual (eg. the priest/shaykh/rabbi or the editor) who holds the position. The priest or the editor may be in the position to use the media (pulpit or the [religious] newspaper) for his/her own ends, and thus defeat the objective of the instrument that lays in his/her hands. At this point we turn our attention to the position and place of religion and media in Southern Africa and demonstrate where and how they intersect and what the nature of their relationship is within a transformed South African environment.

\section{Southern Africa: the position of religion \& the media}

'Southern Africa' is geographically a clearly demarcated region that includes a number of nation-states; depending upon one's approach and understanding it may differ from one person to the other. This being the case and for our purposes it basically refers to those nation-states that are located closer to the southern part of the African continent; in other words, the term 'Southern Africa' only includes Lesotho, Swaziland, Namibia, Zimbabwe, Mozambique, Botswana and South Africa and excludes all the other nation-states that are bona-fide members of the Southern African Development Community (SADC). Since it will be beyond the scope of 
this essay to deal with each and every nation-state in detail, brief reference will be made to relevant aspects such as the position of and the connection between the media and religion in the mentioned list of countries and a more detailed discussion will be pursued on this theme when focus shifts to South Africa. Before we do that let us offer a brief overview of the region's sociopolitical and religious developments that have given rise to an enabling environment within which religion and the media prospered independently of one another.

\section{The socio-political \& religious developments: a brief overview}

During the time when the region was gradually freeing itself from the yoke of colonialism and imperialism, South Africa remained firmly in the hands of the white minority regime until the middle of the 1990s. Changes were in the offing when countries in the neighbourhood, namely Mozambique and Zimbabwe gained their independence in 1975 and 1980 respectively; the former was released from Portuguese colonial control and the latter shook off white rule to attain its independence. While Namibia, which was still known as South West Africa during these times, was still under the hegemony of South Africa's white regime and was only able to get out of its grip by the mid 1980s. Botswana, which used to be referred to as the Bechuanaland Protectorate, had enjoyed independence since 1966 from Britain thereby enjoying independence much earlier than any other country in the region. Even though socio-political transformation was taking shape at a slow pace and nationalism became the rally call in these emerging nationstates, the infrastructure was being developed; all of the changes that took place were, of course, welcomed in the region. The regional structure, namely SADCC (now SADC), was created and seen as a unifying institution. Among the key stakeholders that worked on the process of transformation were, on the one hand, the religious organisations that threw their weight behind the governments and the liberation movements and, on the other, the countries' media, which made their presence felt via their reports and newsworthy columns.

Transformation in the region was further pushed ahead when South Africa became a democratic state in April 1994. Being the most important economic power in the region, South Africa's entry into the world community generally and the Southern African community more specifically sparked off socio-political changes not witnessed before. It marked the (re)integration of South Africa into SADC and signaled its entrance into a variety of world organisations such as the United Nations and the Organization of African Unity (now African Union). And as soon as it got its foothold into these socio-political institutions, South Africa assisted not only to revitalise the region's flagging economies but also to try and inject new energy into the world bodies with the idea of representing the interest of the communities of the South. Nevertheless, its reintegration and the revitalisation of the region's socio-political and economic activities kindled various sectors: it, for example, adopted a constitution that granted its multi-lingual and multicultural communities the freedom of belief and practice and it also paved the way for the media to have the freedom to express themselves without their news reports being curtailed as had been 
the case throughout the era of the apartheid government. These policies encouraged the religious communities to demonstrate their loyalties towards the state without having to sacrifice or compromise their religious identities and it resulted in the media's desire to be critical for the sake of progress and good governance.

At the regional level significant developments such as the building of religious institutions and the emergence of many print and electronic media have been observed. One of the most exciting outcomes was the formation of community radio stations that has included the creation of many religious stations. And at the international level, a sizeable section of the region's religious and secular communities has been exposed to the entrance of satellite stations via Digital Satellite Television (DSTV) as well as the introduction of other systems to which many of its economically mobile communities have subscribed. For example, there is an array of television networks that offer different and many new programmes; the evangelists have been in the forefront in using TV networks to broadcast their religious programmes. In Botswana, for example, American evangelists have made substantial inroads into the homes of the Motswana and in the process have gained many devoted followers and this has, to some extent, given rise to the flourishing of Charismatic churches. A similar trend has been noted when viewing the position of Muslim communities in the region and the Muslim controlled media; a sizeable number of these Muslims have tuned in to TV stations such as Iqra (a Saudi Arabia controlled station) and Islam TV (a South African based TV channel).

Before we delve into our subject, we need to share some thoughts on the religious mosaic of the Southern African region in order to show why the relationship between religion and the media need to be considered an area of study. Southern Africa has gradually become the home not just of many ethnic and linguistic groups but also the home of many religious communities. We may therefore describe the region as a multi-religious society of which Christianity and African Religious Tradition (ATR) are the dominant traditions and, of course, have the most adherents; however, some scholars dispute the available statistics and have not reached any agreement as to whether the Christians outnumber ATR adherents or vice versa; the case of Botswana is one such example (Haron \& Jensen, 2008). Whatever the actual numerical strengths, the fact is that both are rooted in the Southern African soil and therefore form part of the region's religious mosaic. The other religious traditions that make up this mosaic are the plethora of minority religious communities who mainly reside in the region's growing urbanised towns and cities. They are, inter alia, the Bahai Faith Hinduism, Buddhism, Judaism and Islam communities and their numbers hover between $0.1 \%$ and $2 \%$ of the region's population; it is only in Mozambique where the Muslims' numbers are considered to be about $20 \%$ of the total population. Nonetheless, from among the mentioned minority communities, the Muslims seem to be in the forefront in employing their own media to reinforce their religious identity and to also report and reflect upon issues that related to the global ummah (i.e. world-wide Muslim community). In 
fact, South Africa's Muslims have been actively using their media to propagate their ideas and mediate news items and programmes that are not generally broadcast by the state and commercial media. Let us briefly assess the state of the media industry before sharing thoughts on the connection and the relationship between religion and the media in the region.

\section{Southern Africa's media industry: a pencil sketch}

Returning to the regional scene, there is enough evidence that demonstrates that the state media still dominates the broadcasting sphere (Tomaselli \& Dunn, 2001). However, some of the region's commercial print media, which are based in South Africa, have crisscrossed borders and made their presence felt in the neighboring states as viable newsworthy publications. These print publications have been welcomed by the urbanised, middle-class educated communities who prefer reading critical, analytical news rather than sensational news spewed out by some of the weekly (community) tabloids that came onto the market during the past two years. Complementing the print media has been the electronic media; a media that has extended its tentacles far beyond the borders of its specific countries from where it broadcasts. The South African Broadcasting Corporation (SABC), which is one such example, has managed to broadcast radio and television programmes to parts of the region even though attempts have been made by the SABC to block broadcasts from reaching the neighbouring states such as Botswana. However, what can be ascertained is that the international and regional media have been able to expand their reach and indeed their influence in a subtle way without infringing upon the rights of the neighbouring states.

That said, what has generally been observed in Southern Africa is that the media may fit into one of two categories; the first is the private media that have a friendly relationship with their respective governments and those that have a tense and hostile relationship with their governments (Fabricius, 1999: 81-85). Private media, which exists side-by-side with the state media, has demonstrated that the relationship between themselves and the states within which they operate differ from state to state. The governments of Zimbabwe, Lesotho and Swaziland seem to fall into the last mentioned category because the relationship between the private media and state has been a tendentious one. Maruziva (1999: 53-54) provided a graphic description of the experience of the Daily News' attempts to offer alternative news in an intimidating Zimbabwean newspaper environment in the late 1990s. Although problems have also reared their heads in states such as Namibia, Botswana, Mozambique and South Africa, the atmosphere within which the private media have been functioning has not been as problematic and may be described as friendly and affable.

A quick glance at the media's distribution in these countries will provide an idea of the role and impact of the media in these states. In Mozambique the government manages one daily newspaper and competes with one privately owned daily. In addition to these two dailies, there 
are six private weeklies. And in the electronic sector there are one state TV station, two private TV stations, and seven radio stations; one is state run and all the others are private. From among the seven, two are religious stations: Radio Maria is managed by the Roman Catholic Church and Radio Islam by the Muslim community in Maputo. There are no such private religious radio stations in Botswana of which two are state run and three are private music oriented stations. These stations are complemented by two TV channels of which one is private and the other stateowned. And in the print sector, apart from the variety of magazines, there are two daily - one state and one private - newspapers and five weekly privately owned newspapers (Mochaba et al, 2004: 13-14).

When shifting to Zimbabwe, the scene is radically different from that seen in Mozambique and Botswana respectively. Before the state imposed its will on the media industry, Zimbabwe boasted a variety of print media (www.onlinemedia.com/zimbabwe). However, as a result of media repression some of the print media were forced to close and at present the state firmly manages one TV station and two daily newspapers that are printed in Harare and Bulawayo respectively. The three weekly newspapers, which are privately owned, are closely monitored by the state (Mochaba et al 2003: 107). And although three private radio stations and three internet news sites are in the hands of exiles located in UK, USA, SA and Madagascar, they try to influence opinion from abroad - an exercise that has been extremely problematic and indeed fraught with difficulties. Though a similar situation is witnessed in Swaziland and Lesotho, there are slight differences: the monarchy in Swaziland has a very strong hold over all the media (one radio, one TV station, one evangelical radio station, two newspapers (one state $\&$ the other private) and it muzzles the freedom of expression like the ZANU-PF controlled government in Zimbabwe (Mochaba et al, 2004: 45-46). Even though the restrictions are not as bad as in Zimbabwe and Swaziland, the Lesotho government has been actively monitoring the oppositional voices and their tabloids leading at times to defamation lawsuits as a way of curbing the criticism against the government. There are six weekly newspapers of which one appears in English and Sesotho, three in Sesotho only and two in English only. These are complemented by one TV station and six radio stations of which one is state owned and run and another is a religious station.

Compared to the mentioned countries, it appears that the media enjoys more freedom in Namibia and South Africa respectively. The latter, which will be discussed below, has the most robust media industry in the region and the former which has six newspapers (three dailies and three weeklies), two TV stations (one state and one private), and seven radio stations (one state owned and the rest private); among the radio stations Channel 7 is a private religious radio station located in Windhoek (Mochaba et al 2003: 36). The Namibian media industry is similar to that of Botswana in that it serves a population $+1.8 \mathrm{~m}$ and when looking at South Africa which boasts a population of $48 \mathrm{~m}$ the media scene is vastly different and indeed vibrant. 
When placing the South African print and electronic media in perspective, one has to take into account the fact that it straddled two different socio-political dispensations before and after 1994 . The print media that circulated throughout the apartheid era (namely before 1994) have been divided into two major categories along racial lines: the one was "The White Press" and the other was "The Black Press." The latter was created by the press industries to perpetuate racist thinking among the predominantly oppressed Black communities and to stave off the influence of the liberation movements such as the African National Congress (est. 1912) and Pan African Congress (est. 1959). And the former has been further sub-divided into "The English Press" and "The Afrikaner Press" (Tomaselli, Tomaselli \& Muller, 1987). While these presses were the dominant ones for much of the $20^{\text {th }}$ century, there were also a set of alternative presses that made a substantial contribution towards countering the apartheid regime (Switzer \& Adhikari, 2000). On the whole South Africa's media industry - print and broadcast - is very different and much more vibrant when compared to the industry in each of its neighbouring countries; there is enough evidence to demonstrate that its industry is not only well established but extremely competitive and many scholars such as Keyan Tomaselli and others have written extensively on the South African media industry.

To summarise, South Africa has an array of dailies - 20 in all - in each of its nine provinces it has a number of weeklies - 13, according to the figures released in 2008, and a variety of magazines that cover different sporting codes and many other disciplines. It might, however, be in order to mention some of the secular daily and weekly papers that have occasionally reported on religious affairs and issues. Among the list dailies and weeklies the Sunday Times, The Witness, The Cape Times, Pretoria News, Mail \& Guardian, Die Burger, The Sowetan, The Citizen and Rapport are widely circulated and read. The variety of print media is further complemented by an array of state and private TV \& Radio channels. The SABC TV and radio channels have been the oldest in the country and these were later complemented by a number of privately owned TV and radio stations such as M-Net and e-TV (Mochaba et al 2003: 61-62). And soon after South Africa became a democratic state in April 1994, many community radio stations were launched that served the needs of certain interest groups in different parts of the country. Among the latter religious communities such as the Christians and Muslims managed to set up and sustain their non-commercial radio stations; even though some failed and closed down, there were others that succeeded and have remained active broadcasters.

This pencil sketch, which might not be totally accurate particularly when looking at its list on South Africa, and the fact that it is based upon the information cited on the British Broadcasting Corporation website (www.bbc.co.uk) as well as being provided by Konrad Adenauer Foundation's (www.kasmedia.org) researchers, provides a cursory insight into the number of presses and broadcasting stations that exist in Southern Africa. Although the media in these nation-states have followed secular policies when it comes to dealing with their respective 
eligious communities, they have not shied away from reporting on issues such as religious fundamentalism in or outside their communities. Many of these papers have, as expected, sourced information or international news reports on Islamic fundamentalism in the light of the horrific 9/11 event from international news agencies such as Reuters (www.reuters.com); the text by Botha \& De Beer (2005) is one such example. This proved that the region's media industry has largely been dependent upon international news agencies and thus usually credits these international agencies from which they extracted their texts. Of late the South African media industry stepped up its own efforts and made new inroads in its method of reporting by grooming home grown journalists to report on global events; this method has gradually freed the local industry from being dependent upon Reuters and other similar agencies; this is a move that is encouraging and indeed welcome in the region. We therefore assume that South Africa's media industry will not only assist in offering more accurate reports but also act more sensitively when reporting on matters relating to ethnicity and religion. On this note we turn our attention to the relationship between the media and religion in the region.

\section{The Southern African scene: the relationship between media and religion}

When assessing the relationship between the media and religion one may wish to view it on two interrelated levels. On the one level, the two may be seen as independent entities that operate under different rules and regulations. While the media may be seen as an "agent of socioeconomic (and political) change," religion may be viewed as an "agent" of religio-spiritual change.' And on the other level, they may be viewed as interconnected structures and affected by the same system of rules and together they are "agents of social change" that essentially serve the society in different capacities. Bearing in mind these distinctions, an attempt is made in this section to evaluate their relationship to one another in a changing socio-political environment in Southern Africa during the past decade and more. We should say that because of space limitations and other minor factors we chose to leave out Namibia. Lesotho and Swaziland and begin our assessment with Mozambique before moving on to Zimbabwe and Botswana and lastly focusing on South Africa.

\section{Mozambique:}

Mozambique's 1990 constitution, which was amended in 2005, provided press freedom and freedom of access to information. In Mozambique, where there exists no independent national regulatory body that oversees the media's activities, a statutory structure in the form of the Supreme Media Council was set up to ensure and protect the citizen's rights from the media's excesses. Section 3 of its Press, issued in 1991, clearly spelt out the citizen's rights to receive and impart information, and his/her freedom to express his/her thoughts via the media (Andre, 2007). Based upon Andre's Mozambique Report of 2007, it may be argued that Mozambique's citizens have generally not been restricted in receiving or imparting information and they have been 
assisted by a media industry that has helped to disseminate secular news to all and sundry throughout the country. The state media, which has generally been influenced by Mozambique's Marxist political leadership, mediated news which is secular in nature and has at no stage tried to accommodate the wide variety of Mozambique's religious traditions of which the Christians $(+40 \%)$ and the Muslims (+17\%) form sizeable numbers. However, despite the government's ideological outlook it has encouraged and supported non-governmental organisations to set up community radio stations to reach out to those residing in the rural areas. As a result of this positive attitude, religious organisations and communities have taken advantage of the state communication policies.

In fact, these religious communities have also been encouraged by the country's constitution to create their own print and electronic media. For example, Roman Catholics set up Radio Maria in Nampula Province and the Muslims Radio Islam in Maputo to serve the religious needs of their respective communities. During the early part of 2005 Inter Media undertook a survey of 14 radio stations - state and community - and demonstrated that Radio Maria obtained a 17 percent share in the audience listenership (Andre, 2007). Radio Islam was not included because it only got off the ground in 2005 and is presently seeking funds to set up sister stations in the northern part of Mozambique where the majority of Muslims reside. These developments in the electronic sector show that socio-cultural, linguistic and religious communities have been eager to employ the community radio stations to advance their cause and, like elsewhere in the region, religious communities have not been lagging far behind in registering themselves and vying for community radio licenses to serve the needs of their specific religious audiences.

\section{Zimbabwe:}

Even though Zimbabwe's constitution, as articulated in Chapter 3 Section 20, guaranteed the right to the freedom of expression and that of the individual, the constitution omitted to spell out and guarantee the media the freedom of expression (Mochaba et al, 2003: 107; 111; 114). Despite several requests by the media fraternity to insert this guarantee into the African Union's Human and People's 2002 Declaration of Rights on the Freedom of Expression in Africa, their efforts have not been rewarded and the struggle to have this realised seems to be ongoing. Ironically, Zimbabwe has been a signatory to the Windhoek Declaration of 1991, which stated that "African states should be encouraged to provide constitutional guarantees of freedom of the press and freedom of association and expression" (Mukundu, 2006: 21).

Regrettably, the Zimbabwean situation has further deteriorated since 2000, and this has resulted in the imposition of laws that literally restricted the operations of a free media; this has been tangibly reflected in the Broadcasting Services Act of 2001 and the Access to Information and Protection of the Privacy Act of 2002: the latter set out the conditions under which foreign journalists may work and the former banned the broadcast of political news by private media institutions. While the Zimbabwean Independent and The Standard, for example, have come 
under constant fire from the state for the types of stories that appeared since 2003, others such as The Tribune and The Daily News were closed down. As a consequence of an unfriendly media environment radio stations have been set up outside Zimbabwe to offer alternative insights into the Zimbabwean scenario.

The newspaper reports and radio/TV broadcasts - in and outside Zimbabwe - like their counterparts in the region have, on the whole, been disseminating reports and broadcasts that concentrate on the socio-economic and political affairs of the state and avoid religious programming. According to Mukundu (2006:34) several magazines such as Trends that concentrate on social and religious matters were launched in 2000. All of them, however, steered clear of touching upon controversial socio-political issues in order to remain economically afloat and socially relevant. The AMDI Research Summary Report (2006:32) mentioned that the state broadcasting institutions provide a high percentage of religious programming in Zimbabwe to neutralise the views of the populace regarding the political situation in the country. The occasional overlap between religion and politics appear to have taken place when Zimbabwe's religious leaders - and their co-partners in the region - spoke out against the government's intransigence towards serious socio-political change. For example, the Southern African Catholics Bishop Conference (SACBC) has been highly critical of Zimbabwe's policies and have demanded that the international community take a firm stand against the Mugabe regime to bring about radical political reform. As expected, Mugabe vehemently responded to the SACBC and those supporting its call. Since the majority of the media has been state run, the relationship between the state media and the religious communities has been difficult and one that has remained complicated: this may be attributed to those religious groups who support the status quo as opposed to those, such as SACBC, who constantly speak out against the regime's policies.

\section{Botswana:}

Though the media in Botswana enjoy the freedom of expression, there have been times when the voices of the media were muzzled because of the nature of their political reports, which have been regarded by the government as negative (Mochaba et al, 2004: 17).Unfortunately, Botswana does not have a statutory body that regulates the media and with the new laws that were devised in mid 2005, the intention was to establish a Media Council. In the meanwhile the Press Council of Botswana (est. 2004) has been partially doing the job that was supposed to be carried out by the statutory structure.

When assessing the relationship between the media and the religious communities, the bond may generally be described as a gracious one. This is based on the fact that the published reports, with a few exceptions, have generally been sensitive and newsworthy. The connection has also been enhanced by the friendship that exists between, for example, the Botswana Christian Council and the media industry. During the past few years there has largely been no negative reporting in the 
daily and weekly tabloids as well as the radio/TV channels. The two issues that may be regarded by Muslims as a form of sensationalist and negative reporting over the past few years was the "halaal" issue and the suspicious reports of Al-Qaeda sleeper cells located in Botswana; the former issue have indeed occupied the minds of the Motswana and was quite intense towards the end of 2006. In fact, towards the end of 2007 Mmegi reported that the present president chose to step into the debate by decisively deciding that an end of some should be brought on the matter; as far as one is informed, this has not helped much and further inflamed the debate which has resulted in a deafening silence since then.

The Al-Qaeda issue has, however, reared its head again: according to the latest issue (1 February 2008) of the Sunday Standard, a Botswana weekly, it was reported that many North Africans (Egyptians) and South Asians (particularly Pakistanis), who have been implicated in being associated with Al-Qaeda, have come to Southern Africa where they found safe havens for themselves and, in the process, have created what has been described as "Al-Qaeda sleeper cells." How true this is is hard to establish because the newspaper report does not speak about having identified hard evidence that link them to Al-Qaeda. From the Muslim point of view, it is suspected that the intelligence communities from the region have come under the influence of the American (and also the Israeli) intelligence services to be wary of North African and South Asian Muslims migrating to Southern Africa: one of the arguments supporting this view is that these individuals are somehow suspected to be nassociated with "Al-Qaeda," the Middle East terrorist group (Botha 2008: 77). Another view that has been circulating is that in identifying criminal activities (such as the smuggling of drugs and the laundering of monies) the one option to apply was "Al-Qaeda" bogey. As a consequence of these developments, the media such as the Sunday Standard have, in a sense, unsettled the local Muslim community and have contributed to the Islamophobia that is widespread in Europe and the North American continent. Although the issue is not a major factor in the region, reports such as the one mentioned, do at times cause unnecessary tension within the religious communities of Botswana.

Returning to the general relationship between religion and the media, the AMDI Summary Report of 2007 noted that the state media provides, at least, 3 percent of space for religious programmes. When one watches the Sunday TV programmes - whether it is Gaborone TV or BTV - it is obvious that Christian programmes have been amply accommodated by the state. Similar observations may be made of the different state radio stations that play gospel music at regular intervals: genre of music that underlines a flourishing Christian identity in Botswana. These stations, as a matter of fact, are complemented by the many foreign TV and radio religious - particularly Christian and Muslim - broadcasts that have found their way via DSTV into Botswana thereby adding and reinforcing the presence of religion in the country. It is, however, assumed that if the Botswana government had permitted the setting up of community newspapers or radio stations then the Christian organisations would - with the help of foreign investments - 
have set up Christian community tabloids and radio stations as has been the case in South Africa to which we now turn our focus. In fact, South Africa's print and electronic media has for years successfully invaded neighbouring territories which has resulted in the region's communities being well informed about South Africa's socio-political and economic affairs.

\section{South Africa}

As mentioned in the previous summary on Botswana's media, some of South Africa's print and electronic media have crossed Botswana's borders and went on to unintentionally dominate its media landscape. From a purely South African viewpoint this works in the favour of the South African media industry and is proof that because of its competitiveness and resilience it has managed to reach out and prosper in markets far beyond its geographical borders. On the whole, the South African media industry has remained and continues to be the most vibrant in the region and has contributed to a media environment that has remained buoyant and robust.

There is little doubt that it was South Africa's Bill of Rights of 1996 that created an environment in which the society and its variety of structures, such as the media, are able to operate dynamically and freely. T.his is fundamentally attributed to the fact that the media is guaranteed the freedom of expression and association. In fact it benefitted much from the freedom of speech, freedom of the press and freedom of association clauses enshrined in the constitution. Since South Africa transformed itself into a democratic state at the end of April 1994 and adopted the mentioned constitution in 1996, the print and electronic media has expanded rapidly and radically changed the media landscape. South Africans witnessed the emergence of tabloid media and the liberalisation of the airwaves that led to the formation of a plethora of community radio stations including religious radio stations (Hadland, 2007: 51; Milne \& Taylor, 2007: 33).

Apart from the appearance and formation of these new media, statutory and non-statutory bodies also came into existence. One of these was the Media Development and Diversity Agency (MDDA), and another was the Independent Communications Authority of South Africa (ICASA). These and many other NGOs such as the Media Institute of Southern Africa (MISA) and the South African National Editors' Forum (SANEF), which play a critical role in forcing all players - state and non-state actors - to account for their actions (Milne et al, 2007: 50-52). South Africa's civil society was bolstered and supported by these structures and this meant that even the religious communities, who remained active representatives of the civil society, profited from the new environment. As a consequence, a few religious organisations set up religious radio stations to serve the needs of their respective religious constituencies. This was, of course, in addition to the religious print media such as South African Outlook, Muslim News, and South African Jewish Affairs that were already thriving, to a certain degree, during the apartheid era. At this point, we should first say a few words about the secular media and religion before touching upon the religious print media and their successors, namely electronic religious media. 
Even though the secular media's mandate was to report and analyse socio-economic and political affairs, religious issues were also reported on whenever circumstances permitted. This was especially the case when the state and private media reported on and described the role that religious organisations such as South Africa's Chapter of the World Council of Religion and Peace played in the anti-apartheid struggle during the late 1980s and the beginning of the 1990s. And it was so when members of PAGAD, which transformed itself into a vigilante organisation dominated by Muslims in the late 1990s, adopted extremist approaches in their fight against the gangsters and drug dealers. In both instances, the newspapers provided descriptive and analytical reports to demonstrate the part that religion was playing - positive or negative - in social transformation. In the 1980 s the newspapers recorded the contribution of religious radicals and in the late 1990s these and other media reported on the rise of religious fundamentalism; the latter was, by then, a world-wide phenomenon that the target and focus of the national and, of course, the international secular paper, which had extended analytical columns and lengthy feature articles on how religious fundamentalism -the Muslim brand - should be understood and perceived in the late $20^{\text {th }}$ and early $21^{\text {st }}$ centuries.

Apart from the increasing reports on religious fundamentalism particularly after 9/11 which dominated the front pages of the print media, the electronic state media, including TV and radio stations, provided other broadcasting opportunities for the religious communities that steered clear of fundamentalism. In some instances, producers devised programmes and opened up space within which diverse religious issues were aired. There are numerous examples that demonstrate to what extent South Africa has been sensitive to the needs of its diverse religious communities. A few examples at this point will be dealt with in order:

- Radio Sonder Grense has a weekly late-night programme on Thursdays which is devoted to Muslim affairs. It is anchored and presented by Shaheeda Carlie who is in conversation with Shaykh Thafir Najjar, a Cape-based theologian

- Radio 2000, the official 2010 station that intends to concentrate on the World Soccer event, has a weekly programme presented in monologue form by the Chief Jewish Rabbi Warren Goldstein

- Each morning on South Africa's premier radio station, namely SAfm, a religious figure be it a Hindu, Muslim, Jew, Christian, or a Bahai - is given 5 minutes to address any topic or theme from a purely religious perspective

- On SAfm and Talk Radio 702 on Sunday evenings Peter James-Smith and Kate Turkington anchor two weekly open-line religious programmes. Turkington allows for more critical and vigorous debates on a variety of religious issues in her three hour Believe it or not Sunday evening programme, whereas James-Smith adopts a more 
moderate approach to the discussions on religion in his one hour Sunday programme Faith to Faith (Haron, 2002: 119-120)

When it comes to religious discussion on TV, it will be observed that these specially designed programmes are usually flighted on Sundays. SABC TV has, for example, provided separate spaces for Christians, Muslims, Hindus and Jews, and it has also created "religious pluralism" platforms which offer insight into the different religious traditions that have become components of South Africa's rich religious mosaic. Let's share a few examples to show to what degree religious affairs have been slotted into TV broadcasting: $S A B C 1$ at 09:00 broadcasts "Gospel Gold", which is followed by Agape, a Christian religious programme, at 10:00; between 10:30 and 11:00 viewers watch "Chat Room" which is essentially a Christian talk show and at 11:00 it flights "Spirit Sundae" that mainly focuses on prominent and famous personalities who have been deeply influenced and affected by religion. And between 12:00 and 12:30 it broadcasts "An-Nur", which is a weekly progamme that covers aspects of Muslim life. SABC 2, which broadcasts a different menu from that of $S A B C 1$ and $S A B C 3$,, has a weekly programme entitled "Issues of Faith". This multi-religious programme, which broadcasts for one hour from 09:00 to 10:00, has attracted a great deal of viewers because of the interesting manner in which the themes have been dealt with by the presenters. A similar but shorter programme, namely "Free Spirit" appears on $S A B C 3$ between 09:30 and 10:00. And on $S A B C 2$ at 12:00 a special programme titled "Dharma" has been designed for the Hindu community. On $e-T V$, the private TV station, the Rhema Church broadcasts sermons from 05:30 to 06:00 and then again from 08:00 to 08:30 and from 8h30 until 90:00 the Christian programme "Spirit of Praise" is aired. All the mentioned programmes - as well as those not recorded here - suggest that the interests of South Africa's different religious communities are generously catered for through secular oriented media channels.

In the afore-mentioned two paragraphs, it was illustrated to what extent South Africa's state and private secular media offered space to their religious communities; all of them were generally pleased with these broadcasts and particularly with the manner in which their religious traditions were represented in the locally and internationally produced programmes. However, and as expected, these religious communities were not totally dependent upon these programmes nor did they expect to be fully satisfied with what was relayed on radio and TV and nor with what was being reported in the print media: they supplemented these issues with their own print and later- electronic media. Three examples will suffice to illustrate how some of these religious communities produced their newspapers/magazines that covered their interest:

- The Methodist Church published its monthly South African Outlook, now referred to as the New South African Outlook, that did not only deal with mainly religious matters but also covered socio-political issues. This church covered issues differently from the way 
in which the White-dominated Dutch Reformed Church dealt with similar issues in its well-circulated Kerkbode

- The Jewish and Muslim communities adopted a similar approach to that of the Methodist Church by producing and circulating their respective newspapers: the Jews circulated their Jewish Affairs among their devotees and the Muslim community have succeeded in distributing, among others, the Muslim Views and Al-Qalam on a monthly basis over the past 25 years

Furthermore, when new opportunities came their way, South Africa's religious communities quickly took advantage of the Bill of Rights as well as the legislation that covers the media. The broadcasting regulations opened the airwaves and permitted its communities to vie for and establish community radio stations. As a consequence of these exciting developments, Christian and Muslim organisations were among those who successfully vied for community radio licenses. Since it will be difficult to describe and offer a brief analysis of each of the Christian and Muslim community radio stations, it will suffice to mention, at least, two examples to reflect the degree to which media and religion have formed an intimate relationship

- In KwaZulu-Natal Good News Community was established in 1995 and was broadcasting from Verulam in the KZN province. However, it came into conflict with the Independent Communications Authority of South Africa (ICASA) because it was, inter alia, not representative of the community to which it was broadcasting and this resulted in its license being revoked in 2002. After a six year legal battle it managed to get back on air with a new license and frequency. Apart from this Christian radio station Radio Pulpit is the only Christian station that broadcasts nationally. Others such as Radio Veritas and Trans World Radio broadcast via Multi-Choice's DSTV audio channels; and, of late, some of them have gone online and thus reach those listeners who are able access the stations via the internet

- Similar developments were witnessed within the Muslim community which was also able to set up, at least, six Muslim community radio stations of which two are found in Cape Town and two in Johannesburg (Haron, 2002: 121-132). From among the Cape Town stations Radio 786 has been been battling with ICASA for extra frequencies and has faced legal issues brought to ICASA by South Africa's Jewish Board of Deputies (ibid, 126-128). Although this station's license has not as yet been revoked, as was the case with Good News Community Radio, it managed to be representative and produce fairly good community programmes

On this note, it can safely be argued that there exists a fairly good relationship between the secular media and the religious communities. Despite the occasional hiccups that affected their relationship, they administered the links in such a way that the religious communities seldom complained about the bias displayed by the secular media. However, the religious communities 
in South Africa have realised that for them to advance the interest of their respective constituencies they cannot afford to ignore the power and influence of the media and so chose to use the media to assist them to bring about socio-religious transformation. This is further evidence signifying the connection between religion and the media and how it has strengthened and intensified over the last few years and one can imagine that this relationship will expand as these communities are able to become financially mobile.

\section{Towards a conclusion}

In this essay we essentially reflected upon the position and relationship that existed and continues to exist between the media and religion in the Southern African region. The first part highlighted and described the position of both in certain nation-states in Southern Africa, and the second part went on to demonstrate the nature of the relationship between these two sectors in the region. As regards the latter, the essay looked at selected Southern African states and showed how the two sectors interacted - in specific examples it illustrated how the media were in a position - as powerful agents of change - to influence popular opinion about certain religious groups and organisations and it also demonstrated how the religious communities actively employed the media to advance their religious causes. In fact, in some cases these religious communities have proven that with the introduction of the electronic media they are able to reach a far wider audience and have a greater influence upon their flock than they ever imagined.

The essay also demonstrated how the relationship differed from one state to the other because of the interpretation and application of the existing media laws in each of the identified states. A comparison between one state and another demonstrated how the media fraternity and the religious communities enjoy, for example, better opportunities in South Africa than in Zimbabwe. In Zimbabwe freedom to express and freedom to associate have been restricted. In South Africa the media and regious communities have enjoyed unbridled freedom within the confines of the legal system. As a result of this, the South African media industry has been more competitive and robust, and the religious communities have expressed publicly their deep satisfaction with state policies towards religion. They have been able, for example, to practice their religious rituals and build their sacred structures without any meddling from the state; in many other African states beyond the region this has not been possible because of state interference. The South African constitution has, without doubt, played a significant part in the positive attitude its religious communities and media workers displayed towards the state. And to some extent, the constitution was given added support by continental instruments such as the African Charter of Human and People's Rights of 1981, which was enforced in 1986, the Windhoek Declaration of 1991 and the 2001 African Broadcasting Charter. Each of these instruments underlined that Africa's communities like others elsewhere in the "global village" had the right to receive information and the right to the freedom of expression. In Southern Africa the religious communities, which form an integral part of the variety of nation-states, 
benefitted from these instruments in different ways wherever the media was effectively operational; and from within a generally friendly and supportive environment - with a few exceptions of course - a fairly good relationship has developed. This has resulted in a cordial connection between the media and religion which bodes well for the future of the region and each and every nation-state that is a SADC member.

\section{About the author:}

Author: Muhammed Haron

Title: Lecturer at University of Botswana

Current position: Associate Professor

Personal biography: Taught Arabic Studies at University of Western Cape (circa 1982-1998), 'Islam' and 'Islamic Education' at University of Cape Town (circa 1986-1991), 'Sociology of Religion,' 'Philosophy of Religion,' Religion \& Politics' and 'Religion \& Development' at University of Botswana (circa 2000-2010). Published: First Steps in Arabic Grammar [reprints 1997 \& 2007] \& Second Steps in Arabic Grammar (Chicago: Iqra International 2009); Muslims in South Africa: An Annotated Bibliography (Cape Town: SA Library 1997), The Dynamics of Christian-Muslim Relations in South Africa (circa 1960-2000) (Stockholm: Alqmvist \& Wiksell International 2006); and South Africa's Truth \& Reconciliation Commission: An Annotated Bibliography (New York: Nova Science 2009).

E-mail address: haronm@mopipi.ub.bw

Mailing address: Department of Theology \& Religious Studies, PB UB 0703, Faculty of Humanities, University of Botswana, Gaborone, BOTSWANA

Telephone: +26771499646 (cell - Botswana) \& +27826266766 (cell - SA)

\section{References}

Altschull, H. 1995. Agents of power: the media and public policy. London: Longman.

Andre, F. 2007. Mozambique: research findings \& conclusions. London: Africa Media Development Initiative.

Anon (ed.). 2006. The Africa Media Development Initiative. London: BBC World Service Trust..

Beckford, J. A. 2007. Religion and power. In: Robbins \& Anthony (ed.), In gods we trust: new patterns of religious pluralism in America. (Ch.:1: 43-60). New Brunswick: Transaction Publishers.

Botha, A. 2008. Initiatives to prevent and combat terrorism in Southern Africa. In: Okumu, W \& Botha, A. (eds.): Understanding terrorism in Africa:building bridges and overcoming gaps (Pt. 3:.71-89: Pretoria: Institute of Security Studies.

Botha, N \& De Beer, A. 2005. Between Scylla and Charybdis: 911 in South African Media. In: Pludowski, T (ed.): How the world's new media reacted to 911. New York: Marquette Books, LLC. 
Bromley, \& Cushion,S, 2002. Media fundamentalism: the immediate response of the UK national press to September 11. In: Zelizer, B \& Allan, S (ed). Journalism after September 911. (Ch. 9: 160-177). London \& New York: Routledge.

Bruce, S. 1996. Religion in the modern world: from cathedrals to cults. Oxford: Oxford University Press.

Clark, L. Schofield, ? \& Hoover, S. 1997. At the Intersection of Media. Culture and Religion: A bibliographic Essay. In: Hoover, S \& Lundby, K (ed.). Rethinking media, religion and culture. London: Sage.

Corbett, M \& Julia Mitchell Corbett, M. 1999. Politics and religion in the United States. New York: Garland Publishing, Inc.

Crawford, R. 2002. What is religion? London: Routledge.

Curran, J \& Seaton, J. 1997. Power without responsibility: The press and broadcasting in Britain. London: Routledge.

Fabricius, P. 1999. The media in Southern Africa. In: Politics and the media in Southern Africa: seminar report (Pt. II pp. 81-85). Johannesburg: Konrad Adenauer Foundation.

Hadland, A. 2007. The South African print media, 1994-2004: An application and critique of comparative media systems theory. Phd Thesis in Film and Media Studies, University of Cape Town.

Haron, M..2002. The South African Muslims making (air) waves during the period of transformation. In: Journal for the Study of Religion. 15(2): 111-144.

Haron, M. \& Jensen, K. 2008. Religious identity and public health interventions in Botswana. In African Identities: 6 (2):183-198.

Hoover, S. \& Lundby, K. (ed.). 1997. Rethinking media, religion and culture. London: Sage.

Hoover, S. 2006. Religion in the media age. London: Routledge.

Hyden, G,. Leslie, M. \& Ogundimu, F. F. (ed.). 2003. Media and democracy in Africa. London: Transaction Publishers.

Kandjii, K.(ed.). 2001. So this is democracy? State of the media in Southern Africa 2000. Windhoek: MISA.

Maruziva, Davison, S. 1999. Obstacles and challenges facing the media in Zimbabwe. In: Politics and the media in Southern Africa: seminar report: 2:53-54. Johannesburg: Konrad Adenauer Foundation.

Merrit, C. \& Saunders, C. 2000. Weekly Mail (ca. 1985-1994). In: Switzer, L. \& Adhikari, M. (eds.). South Africa's resistance press: alternative voices in the last generation of Apartheid (Ch 11: 458-486). Ohio: Ohio University Press. 
Milne, C. \& Taylor, A. 2007. South Africa: research findings and conclusions. London: Africa Media Development Initiative.

Mochaba, K., Raffinetti, C., Vallabh, S, \& White, J. 2003. SADC Media Law: A handbook for media practitioners - a comparative overview of the laws and practice in Malawi, Zimbabwe, Namibia and South Africa. Vol.(I) . Johannesburg: Konrad Adenauer Foundation.

Mochaba, K., Raffinetti, C. \& White J. 2004. SADC Media Law: A handbook for media practitioners - a comparative overview of the media law and practice in Botswana, Swaziland and Zambia. Johannesburg: Konrad Adenauer Foundation.

Mukundu, R. 2006. Zimbabwe: research findings and conclusions. London: Africa Media Development Initiative.

Murdock, G.. 1997. The re-enchantment of the world religion and transformation of modernity. In: Hoover, S. \& Lundby, K (ed.). Rethinking media, religion and culture. London: Sage.

Said, E. 1981. Covering Islam. London: Routledge \& Kegan Paul.

Said, Edward. 1987. Orientalism. London: Verso Press.

Schultze, Q. J. \& Robert H. Woods, R. H. Jr. (eds.). 2008. Understanding evangelical media:the changing face of Christian communication. Illinois: Downers Grove.

Sechele, T. 2007. Botswana: research findings \& conclusions. London: Africa Media Development Initiative.

Switzer, L. \& Adhikari, M. (ed.). 2000. South Africa's resistance press: alternative voices in the last generation of Apartheid . Ohio: Ohio University Press.

Thomas, Robbins \& Anthony, D. (ed.). 2007. In gods we trust: new patterns of religious pluralism in America. New Brunswick \& London: Transaction Publishers.

Tomaselli, K.,Tomaselli, R.. \& Muller, J. 1987. Narrating the crisis: hegemony and the South African press - addressing the nation. Johannesburg: Richard Lyon \& Co.

Tomaselli, K. \& Dunn, H. (eds). 2001. Media, democracy and renewal in Southern Africa. Colorado Springs: International Academic Publishers.

\section{Websites}

British Broadcasting Corporation www.bbc.co.uk

Christian Action www.christianaction.org.za

Fim D Semana www.fimdesemana.co.mz 
Mmegi www.mmegi.bw

Online Media www.onlinemedia.com

Public Eye www.publiceye.co.ls

Refworld www.unhcr.org/cgi-bin/texis/vtx/refworld/rwmain

Sunday Standard www.sundaystandard.com

The Namibian www.namibian.com.na

The Herald www.herald.co.zw

The Swazi Observer www.swaziobserver.org.sz

Trinity Broadcasting Network www.tbn.co.za 